\title{
O CORPO (NÃO) HUMANO E SUA IMPORTÂNCIA NA QUESTÃO IDENTITÁRIA: O MONSTRO DE FRANKENSTEIN OU PROMETEU MODERNO
}

\author{
THE (NON) HUMAN BODY AND ITS IMPORTANCE ON \\ IDENTITY: THE MONTER OF FRANKENSTEIN; OR THE MODERN \\ PROMETHEUS
}

Eugênia Adamy Basso

Eduardo Marks de Marques

\begin{abstract}
RESUMO: O presente artigo tem como objetivo a análise das concepçōes de corpo, suas bestializaçōes e as questōes de aceitaçăo e formaçâo de identidade que o envolvem, tomando como objeto de análise a obra de Mary Shelley Frankenstein ou o Prometeu moderno. O estudo procurou uma discussâo acerca do lado humano e năo humano da criatura de Frankenstein, sua estrutura e comportamento corporal bestializados e sua identidade frágil, acompanhada de uma intensa agressividade. Para desenvolver o trabalho, foram utilizados como revisâo de literatura teóricos que dissertam sobre corpo e identidade (Kathryn Woodward), bios e zoo (Giorgio Agamben) e comportamento corporal (Michel Foucault), além de uma comparaçâo do processo de criaçâo elaborado por Victor Frankenstein com o processo de criaçăo divina do Homem.
\end{abstract}

PALAVRAS-CHAVE: Corpo. Identidade. Bestializaçăo. Humano. Frankenstein.

ABSTRACT: This paper has as objective the analysis of the conceptions of body, its bestialization and the ideas of acceptation and identity formation that are involved. For that, the object of analysis is the novel Frankenstein: or the Modern Prometheus, by Mary Shelley. The study approached a discussion about the human and not human sides of Frankenstein's creature, its structure, the grotesque body behavior, and its fragile identity, together with an intense anger. To develop this study, we studied theoretical authors who research about body and identity (Kathryn Woodward), bios and zoo (Giorgio Agamben), and body behavior (Michel Foucault), besides a comparison of the process of creation elaborated by Victor Frankenstein as the process of divine creation of Man.

KEYWORDS: Body. Identity. Bestialization. Human. Frankenstein. 
“Meu corpo, năo meu agente,

meu envelope selado,

meu revólver de assustar,

tornou-se meu carcereiro,

me sabe mais que me sei."

Carlos Drummond de Andrade

Discussóes sobre o corpo fazem-se presentes em várias áreas de conhecimento. Umas utilizam o corpo como instrumento de pesquisa - para investimento na saúde e para investimento estético; outras utilizam o corpo para realizar discussóes acerca de sua importância e representaçăo nas relaçóes humanas. Nas artes, o corpo é explorado como vetor de performances, algumas delas comuns no nosso dia a dia: dança, fotografia, interpretaçăo musical, artes cênicas, contos e romances eróticos. Temos, entăo, a partir dessas manifestaçôes corporais, um forte modelo estético e expressâo cultural. Em meio a tantas representaçôes vindas de diversas áreas, torna-se importante discutir o que é o corpo e como nos manifestamos por meio dele.

Ao falarmos em corpo, deparamo-nos com várias definiçóes, de acordo com o ponto de vista de cada âmbito que o utiliza. Conforme passa o tempo, surgem novas pesquisas, novos teóricos e, consequentemente, novas definiçóes sobre o corpo humano. Dentro disso, Campello e Schimidt realizam um estudo acerca das inter-relaçóes de corpo e mente na formaçáo do sujeito, o que acrescenta positivamente às discussóes sobre formaçăo identitária dentro do meio:

Ao longo da história, o corpo foi colonizado pelas práticas discursivas da filosofia e das ciências naturais e sociais, campos minados por pressupostos sobre sua natureza, seu estado bruto como um já-dado, imutável, inerte e passivo, sua constituiçăo biológica e pré-cultural e sua imunidade aos fatores históricos, sociais e culturais. De qualquer forma, até recentemente, o corpo foi pensado, predominantemente, de acordo com valores sociais, morais e religiosos, e particularmente, em termos da constituiçăo binária de dois sexos, o masculino e o feminino. (CAMPELLO e SCHMIDT, 2015, p. 10)

Neste artigo, os conceitos e as noçôes utilizadas provêm de uma proposta sociológica, que define o corpo como um vetor de experiência, ligando-nos ao ambiente externo e nos permitindo vivenciar as sensaçôes do mundo: “O corpo é a matéria encarnada que nos constitui e que habitamos, a fronteira física que permite o reconhecimento de um existir no mundo" (IBIDEM, p. 9). Cada indivíduo tem seus próprios resultados de acordo com o que experimenta a cada momento: o corpo lhe serve como fronteira, e cada percepçáo sobre a vida e o mundo é armazenada em sua mente (imaterial), ligada ao cérebro (material). Desse modo, podemos entender que a mente humana é a força motriz do nosso corpo, e que tal conjunto nos permite atuar na sociedade, influenciando na constituiçấo de nossa identidade.

O corpo é uma entidade que pode nos unir com suas semelhanças e, também, separar-nos. Somos definidos por meio de comparaçóes com demais indivíduos - ou reconhecemo-nos no outro, ou o identificamos como alguém ou algo que năo somos. Para 
Woodward (2000, p. 15), "o corpo é um dos locais envolvidos no estabelecimento das fronteiras que definem quem nós somos, servindo de fundamento para a identidade". Ao percebermos essas diferenças e semelhanças corporais, automaticamente criamos grupos diferentes na sociedade a partir da performance de cada um. Ainda para a autora, (2000, p. 50), "a diferença pode ser construída negativamente por meio da exclusâo e da marginalizaçăo daquelas pessoas que săo definidas como 'outros' ou 'forasteiros'". Em um contexto em que há o corpo padrăo e o năo padrâo, o corpo aceitável e o nâo aceitável, temos a noçâo do corpo năo hábil: nele, enquadram-se os indivíduos que nâo săo estăo nos padrôes de um ser humano "perfeito", com dois braços, duas pernas ou sem qualquer deficiência. Também, há as noçôes de bestializaçăo, o corpo grotesco ou o corpo nâo humano. Porém, o que nos faz humanos? Ser humano é apenas questâo de estética ou há, dentre demais fatores, a identidade e os sentimentos a ela relacionados? Partindo desses questionamentos, o objetivo deste artigo é fazer uma análise do que pode ser considerado humano ou năo humano no monstro presente na obra Frankenstein ou o Prometeu moderno, de Mary Shelley, publicada primeiramente em 1818, na Inglaterra.

Victor Frankenstein é um homem complexo. Sua infância, no início, parecia adorável: Em seu primeiro relato para Walton, quando é socorrido em pleno mar e prestes a morrer, Frankenstein afirma: "Quando conhecia de perto outras famílias, eu percebia distintamente o peculiar privilégio que era pertencer à minha, e a gratidăo só fazia aumentar o amor filial" (SHELLEY, 2015, p. 106). Essa atmosfera tranquila e graciosa em que Victor vivia ajudava no seu bem-estar: sua paixâo era conhecer as ciências naturais: "Já me descrevi como alguém permanentemente imbuído de uma fervorosa necessidade de penetrar os mistérios da natureza" (p. 108). No entanto, a partir da morte de sua măe, sua vida perde um pouco do encantamento.

Ao chegar à faculdade, inicia seus estudos com o sr. Waldman, mergulhando nas teorias de filosofia natural e química. Lá, Victor teve a oportunidade de sanar suas maiores curiosidades, sendo uma delas a estrutura dos corpos:

Um dos fenômenos que de maneira mais peculiar chamavam-me a atençăo era a estrutura do corpo humano; na verdade, de qualquer animal imbuído de vida. De onde, eu frequentemente me perguntava, vinha o princípio vital? (p. 124)

Sendo assim, o pesquisador adentrou na área da anatomia. Em seu laboratório, vida e morte o fascinavam: surge, entăo, a ideia de executar a experiência do surgimento da vida:

Năo haveria pai que pudesse reivindicar tamanha gratidăo de um filho quanto a que eu merecia de minhas criaturas. Ao desenvolver tais reflexóes, pensei que, se eu era capaz de presentear com a vida a matéria morta, talvez pudesse, com o tempo (embora hoje tenha descoberto ser isso impossível), fazer reviver um corpo que a morte aparentemente condenara à deterioraçáo. [...] Quem poderá conceber os horrores de minha labuta secreta, a revolver o pântano profanado das sepulturas ou a torturar um animal vivo pela possibilidade de reanimar o barro sem vida? (p. 127, grifo meu)

Na narraçăo de Victor, o corpo humano surge do barro, assim como a criaçăo do homem, feita por Deus: “[...] No suor do rosto comerás o teu păo, até que te tornes à terra, pois dela foste formado: porque tu és pó e ao pó tornarás" (GÊNESIS, 3:10, grifo nosso). 
Também como um Prometeu ${ }^{1}$ do século XIX, Victor estabeleceu como objetivo inadiável a elaboraçáo de um novo ser e, para isso, ficou confinado por meses em sua sala, fracassando e retomando novamente, obstinado com seu projeto, sem manter contato com mais ninguém. Em um dia de novembro, terminado o projeto, Victor Frankenstein dá vida a sua criatura:

Os membros eram proporcionais e os traços que eu escolhera para ele eram belos. Belos! - Meu Deus! Sua pele amarelada mal dava conta de encobrir o mecanismo de músculos e artérias debaixo dela; seu cabelo escorrido era de um preto lustroso; os dentes, de um branco perolado. Tais características luxuriantes, porém, apenas tornavam mais horrendo o contraste com o rosto enrugado, os lábios negros e retos e os olhos aquosos, os quais pareciam quase da mesma cor branco-acinzentada das órbitas em que se encaixavam. (p. 131)

O primeiro contato que Victor estabelece com a criatura é de pavor: ele cria repulsa de sua aparência monstruosa e grotesca e acaba por năo conseguir assumir seu papel de criador, năo se responsabilizando pelo que criou. Portanto, Frankenstein abandona seu filho, pois ele é uma aberraçăo, é um experimento que, futuramente, acaba por "nâo dar certo por ter dado certo". Após ter visto a criatura com vida, o pesquisador nâo pensou nas consequências deste ser: suas necessidades e suas relaçóes com o mundo. 0 medo da responsabilidade do que fazer com aquela vida lhe pesou demais, fazendo com que ele fugisse. Logo, Victor se torna a pessoa mais egoísta do romance e desenvolve, de fato, uma criatura agressiva.

A posiçáo de Victor como criador pode ser associada à posiçăo divina: seria uma transgressâo do ser humano para a posiçấo de Criador - aqui, a palavra se apresenta com letra maiúscula, pois se trata de Victor em comparaçâo com Deus da Bíblia cristâ, que fez o homem à sua imagem e semelhança. No entanto, a sua rejeiçăo pelo monstro faz com que ele rejeite, também, sua posiçâo divina. Interessante analisar, também, que o monstro náo se vê como inferior ao seu criador, pois ele nada sabe sobre cultura e religiâo: ele age puramente pelos instintos e pela razăo, sem dogma religioso. Podemos perceber que, na obra de Mary Shelley, temos um questionamento da autoridade divina, se compararmos Victor Frankenstein com o Deus do cristianismo: o Senhor nos cria como sua imagem e semelhança, mas ele está acima dos seres humanos, sendo nosso superior. A bíblia desde o início mostra a hierarquia entre Deus e o homem, este tendo seu destino traçado:

Tomou, pois, o Senhor Deus ao homem e o colocou no jardim do Éden para o cultivar e o guardar.

E lhe deu esta ordem: De toda árvore do jardim comerás livremente,

Mas da árvore do conhecimento do bem e do mal năo comerás; porque no dia em que dela comeres, certamente morrerás. (GÊNESIS, 2:15-17)

Acima, é nítida a presença de poder do Criador sobre a criatura, pois lhe estabelece regras e consequências em caso de descumprimento. A nossa relaçăo com o ser humano é de igualdade, e náo de superioridade. Nós năo nos relacionamos com Deus como nos

1 Prometeu é um tită da mitologia grega, que foi incumbido da criaçăo do homem e dos animais. 
relacionamos entre os homens: por ele ser superior que nós, aprendemos culturalmente a adorá-lo. Deste modo, o monstro criado por Victor desenvolve uma adoraçâo e uma dependência extrema do seu seguidor.

Em um determinado momento, após se deparar com sua criaçăo, Victor imediatamente se arrepende e se ausenta de sua vida, pois ela lhe causa nojo. Na bíblia, Deus também sente, em certo momento, um arrependimento de ter criado a espécie humana, pois eram tantos os pecados do Homem na terra que Deus se arrepende de ter o criado. Sua atitude, entâo, é de provocar o dilúvio, dando seguimento ao episódio da Arca de Noé, em que apenas um par de cada espécie poderia sobreviver, havendo um par de seres humanos. Isso comprova que Deus, diferentemente de Victor, apesar de se arrepender de sua criaçăo, năo deixa de investir em uma melhora no caráter da espécie e nấo a abandona. Frankenstein ignora a presença de sua obra e a deixa solta no mundo, sem dar importância para sua formaçăo. Na história, a criatura se vê como um filho de Victor, mas năo o é. Ao chamarmos Deus de Pai, estabelecemos uma relaçăo que é paternal, sendo esta ausente fisicamente e unilateralmente ou bilateralmente correspondida. A mesma situaçăo ocorre do monstro para o médico: a relaçáo é unilateral, pois năo há correspondência da parte do criador.

As relaçôes entre Victor e o monstro sâo baseadas em abandono. Além disso, tendo sido recusado pela figura paterna, o corpo monstruoso foi um fator definitivo no desenvolvimento da criatura. Retomando a questáo de que o corpo é um vetor de experiência, servido como fronteira entre nosso interior com o mundo exterior, em um de seus estudos sobre corpo e sociedade, a pesquisadora Marisa Lima afirma que:

O corpo năo é, pois, um objeto. Sua imagem é o conceito e a vivência que se constrói sobre o esquema corporal, trazendo consigo o mundo das significaçóes, e na imagem estáo presentes os afetos, os valores, a história pessoal, marcada nos gestos, no olhar, no corpo em movimento, que repousa e que simboliza. (LIMA, 2013, p. 3)

Ao carregar a história individual de quem o habita e assimilando, também, influências do outro, cada um de nós forma nossa personalidade. O monstro de Frankenstein foi criado por meio da junçâo de diversos pedaços humanos, de pessoas que já haviam falecido, ficando com uma aparência horrorosa. Desse modo, podemos afirmar que ele é um amontoado de pedaços com história, que viveram e assimilaram muitas coisas do mundo. Que história esse amontoado de pedaços tem? No momento que eles săo apenas corpos, eles perdem suas identidades, pois a "alma" ou a "mente" năo estấo com eles, além da ausência da personalidade. Vitor poderia ter pego um corpo inteiro e ressuscitá-lo, mas isso seria lhe dar vida novamente, uma ressurreiçáo, náo uma criaçáo. Haveria, portanto, uma retomada de identidade e náo o surgimento de uma nova.

A criatura de Frankenstein foi ignorada pelo pai, devido à sua aparência horrenda, totalmente distante dos padróes estéticos do contexto em que se passa a história um indivíduo com o corpo bestializado, comparado ao animalesco e ao grotesco, năo tendo, sequer, um nome. Na história, a criatura é tratada como um monstro, causando histeria por onde passa. Em seus estudos sobre o grotesco, os pesquisadores Muniz Sodré e Raquel Paiva retomam as ideias sobre os aspectos e o percurso histórico dessa categoria, principalmente na área artística. Para os autores, 
Trata-se da mutaçăo brusca, da quebra insólita de uma forma canônica, de uma formaçáo inesperada. A dissonância năo se resolve em nenhuma conciliaçáo, já que daí decorrem o espanto e o riso, senăo o horror e o nojo. (2002, p. 25).

Com relaçăo, também, à recepçăo do grotesco, Paiva e Sodré colocam que somos afetados, a todo instante, por cores, volumes, narrativas e frases. Nos caminhos entre o real e o imaginário, o grotesco está ligado à

[...] sensibilidade espontânea de uma forma de vida.Éalgo que ameaça continuamente qualquer representaçăo (escrita, visual), ou comportamento marcado pela excessiva idealizaçáo. Pelo ridículo ou pela estranheza, pode fazer descer ao chăo tudo aquilo que a ideia eleva alto demais. (2002, p. 39)

Na história, o monstro de Frankenstein causa o nojo e o estranhamento, pois, do ponto de vista humano, sua aparência está longe do padrăo idealizado socialmente. Além disso, para as pessoas, seu comportamento condiz com seu físico, estando sua agressividade associada ao horror. No entanto, podemos supor que isso está ligado à falta de identidade e ao abandono que a criatura enfrenta.

Durante muito tempo, o monstro faz várias tentativas para obter reconhecimento. Se nos colocarmos em seu papel, podemos traçar um paralelo que contribuiu para sua conduta agressiva e assassina: ele "nasceu", já adulto, em um ambiente desconhecido, sem saber falar nenhum idioma, sem ter para quem pedir auxílio e sem ter onde morar. Em suas palavras:

"Estava escuro quando acordei; sentia frio também, e um pouco de medo, por assim dizer, instintivamente, por me ver tăo abandonado. Antes de sair de teus aposentos, sentindo frio, cobri-me com algumas roupas, mas elas foram insuficientes para me proteger do sereno da noite. Eu era um pobre ser indefeso e miserável; năo sabia nem era capa de distinguir nada. Invadido de dor por todos os lados, sentei-me e chorei." (SHELLEY, 2015, p. 190)

A busca constante para ser reconhecido como alguém é muito forte nesta personagem. Apesar de ser grotesco na história, o monstro procura sempre auxílio de um ser humano para poder se integrar na sociedade, o que reforça o quăo importante é, para um indivíduo, ser aceito e ter segurança de pertencimento. Em seu trabalho sobre identidade e diferença, Tomaz Tadeu da Silva nos mostra que a identidade pode ser definida a partir das diferenças e que, assim como a linguagem, ela pode ser concebida por meio de fixaçăo. Porém, ela nâo é totalmente estável e acaba por estar ligada aos sistemas de representaçăo, tendo em vista que é um significado cultural.

A afirmaçăo da identidade e a marcaçăo da diferença implicam, sempre, as operaçōes de incluir e de excluir. Como vimos, dizer "o que somos" significa também dizer "o que năo somos". A identidade e a diferença se traduzem, assim, em declaraçóes sobre quem pertence e sobre quem náo pertence, sobre quem está incluído e quem está excluído. Afirmar a identidade significa demarcar fronteiras, significa fazer distinçôes sobre o que fica dentro e o que fica fora. A identidade está sempre ligada a uma forte separaçâo entre "nós" e "eles". (SILVA, 2000, p. 82)

Entendemos, entâo, que a criatura se percebe e é percebida como alguém nâo humano, năo conseguindo encontrar representaçăo em nenhum outro grupo. A partir de entấo, a solidáo do monstro se configura em um estado de abandono, tanto social 
quanto paternal. Nos estudos de Edna Hogemann e Solange Moura, pesquisadoras na área do Direito, há um artigo dedicado à questâo da construçâo do sujeito, seu acolhimento e os problemas do abandono. Para as autoras:

A identidade pessoal, num refletir psicológico, é a maneira pela qual as pessoas enxergam a si mesmas e está intimamente relacionada à própria imagem. É deveras importante, na medida em que influencia o modo como as pessoas se sentem e de como se comportam em situaçóes desafiadoras. Outro aspecto particularmente importante sobre a identidade pessoal é a possibilidade de se enxergar exatamente como as outras pessoas nos enxergam quando se está em harmonia com os outros e com o mundo no entorno, ou pode ser muito diferente quando năo se está em harmonia com elas provocando um sentimento de grande batalha para nos tornarmos apreciados pelas pessoas pelo que se realmente é. Sob um vislumbre sociológico, a identidade pessoal é um construir-se através do processo de socializaçâo, que se dá até a morte. (HOGEMANN; MOURA, 2013, p. 58)

A criatura abandonada é vítima de várias rejeiçōes e preconceitos, sofrendo, muitas vezes, agressōes verbais e, até mesmo, físicas. O monstro năo conseguiria jamais, nesta situaçăo, enxergar-se como os demais e viver de maneira harmoniosa. Inicialmente, ele năo entendia os motivos de ser tratado como um ser repulsivo, mas, após enxergar-se nos reflexos da água e comparar-se com as demais pessoas que já havia encontrado, ele percebe o motivo de sua rejeiçáo e se reconhece como um monstro. A partir de entăo, fica um questionamento: se a criatura é feita com membros humanos, mas nâo é reconhecida como tal para os demais, seria ela humana ou năo? O que é, afinal, ser humano?

Primeiramente, antes de analisar o perfil da criatura de Frankenstein, é necessário discutir o que faz um indivíduo ser humano. Para isso, é interessante retomar a discussâo de bios e zoo, de Giorgio Agamben, que retoma uma distinçáo vinda dos gregos entre os seres humanos e os animais. A ideia de bios é a vida em uma organizaçấo social racional; zoo é uma ideia primitiva de vida, como as dos demais animais.

\begin{abstract}
Este projeto começou de uma observaçáo de que os gregos năo tinham um termo singular para expressar o que entendemos pela palavra vida. Eles fizeram uso de dois termos distintos semanticamente e morfologicamente: zoo, o qual expressava o simples fato comum de viver, assim como todas as coisas vivas (animais, seres humanos ou deuses), e bios, o qual significava a forma ou a maneira de vida própria de um indivíduo ou grupo. Nas línguas modernas, nas quais essa oposiçăo gradualmente desaparece a partir do léxico (onde está preservado, como na biologia e zoologia, náo indicando uma grande diferença), um termo solo - de quem a opacidade cresce a uma extensâo proporcional à sacralizaçâo do seu referente - designa uma pressuposiçáo de que é sempre possível fazer isolamentos em cada uma das inúmeras formas de vida. (AGAMBEN, 2016, p. 204, traduçăo nossa, grifos do autor).
\end{abstract}

A questăo da racionalidade e inteligência humana é muito cobrada na sociedade. Tais aspectos tornam os humanos frágeis, com medo de que outras criaturas possam surgir e serem mais inteligentes que eles. O ser humano acredita ser o centro do universo, pois, se há outros seres vivos, ele os compara com ele próprio, sendo um ponto de referência. Isso náo ocorre somente com a questăo de inteligência, mas com o comportamento, a postura e a estética humana: Frankenstein era rejeitado por nâo alcançar um padrăo humano de referência, por năo ser civilizado e ser visto como um monstro. 
Muitos seres vistos como monstruosos podem ter a aparência de um ser humano, como os vampiros, lobisomens e bruxas. Porém, outros săo fisicamente assustadores, como a criatura de Victor. Sendo assim, um monstro é uma entidade năo humana, estranha para sociedade. O psicanalista Sigmund Freud abordou a temática do estranho em seus estudos, tratando sobre a repetiçấo: o estranho, mesmo aparecendo repetidamente, ainda pode se apresentar como algo diferente.

O tema do 'estranho' [...] relaciona-se indubitavelmente com o que é assustador - com o que provoca medo e horror; certamente, também, a palavra nem sempre é usada num sentido claramente definível, de modo que tende a coincidir com aquilo que desperta o medo em geral. (FREUD, 1976, p. 14, grifos nossos)

Para aprender a se comunicar e a viver como um ser humano, a criatura abandonada vai para um chalé, e lá vive escondido, lendo os materiais de Victor Frankenstein e observando a vida de uma família que ali vive, desenvolvendo, por eles, afeto. Um dia, esperançoso, a criatura, sabendo de sua aparência horrenda, resolveu se revelar para todos, esperando aceitaçâo:

“'Deus Todo-Poderoso!', exclamou o homem. 'Quem és tu?' Nesse instante, a porta do chalé se abriu e Felix, Safie e Agatha entraram. Quem conseguiria descrever seu horror e sua consternaçăo quando olharam para mim? Agatha desmaiou e Safie, incapaz de socorrer a amiga, correu para fora do chalé. Felix avançou como uma flecha e, com uma força sobrenatural, arrancou-me seu pai, a cujos joelhos eu me agarrava. Num acesso de fúria, lançou-me ao chăo e bateu violentamente em mim com uma vara. (...)" (SHELLEY, 2015, p. 227)

Acima, temos a descriçăo do episódio que mais marcou a criatura da obra, deixando-o traumatizada com relaçâo a sua aparência monstruosa. As pessoas por quem ele foi cativado, ao olharem para ele, sentiram uma total sensaçáo de estranhamento, năo possibilitando sequer que ele se apresentasse. 0 medo e a histeria foram coletivos, fazendo com que o monstro tivesse que ir embora da casa.

A partir de entăo, a criatura cria uma sensaçăo de revolta, ao mesmo tempo que se torna cada vez mais carente e solitária. Para isso, ela recorre ao seu criador, pedindo que este lhe faça uma mulher, para que seja sua companheira: "Deves criar uma mulher para mim, com a qual eu possa viver uma troca de solidariedade necessária à minha existência" (p. 238). A ideia do monstro era que, ao receber uma companheira que fosse sua semelhante - tanto com relaçăo à aparência quanto com relaçăo ao comportamento - ele iria embora para viver somente com ela, podendo dividir sua vida com alguém que o aceitasse. Porém, seu criador recusa a proposta, alegando: "Criar outro ser como tu, cuja maldade, somada à tua, traria desolaçâo ao mundo!" (p. 238). Isso deixa o monstro ainda mais irado, pois fica convicto de que seu destino é a solidăo.

Além da carência de companheirismo e acolhimento paterno, a criatura também demonstra ter necessidade de ser reconhecida como um indivíduo, principalmente com relaçăo ao reconhecimento paterno de Victor, sendo seu filho. O monstro tem plena consciência de que seu problema foi o abandono desde o início de sua vida:

"Mas onde estavam meus amigos e minhas relaçóes? Nâo tivera um pai a testemunhar meus tempos de bebê nem a bênçáo de uma máe, seus sorrisos e carícias; ou, se tivera, meu passado inteiro agora era um borrăo, um vazio escuro no qual eu nada distinguia. Em minha lembrança mais remota sempre fui este mesmo ser, deste 
tamanho e desta altura. Até ali jamais vira outro que se assemelhasse a mim ou que quisesse ter alguma relaçáo comigo. O que eu era? [....." (p. 211)

Na passagem acima, notamos que a criatura de Frankenstein năo entende como veio ao mundo, pois seu passado lhe é obscuro. Além disso, ela nâo entende que tipo de ser ela é e, durante a obra, ela busca essa resposta, apesar de ser sempre rejeitada pelos demais.

Os traços até aqui abordados - carência e necessidade de reconhecimento - sâo características humanas. Um dos maiores medos do ser humano é ficar sozinho, sem ter alguém para dividir momentos, sem ser aceito no convívio em sociedade e, pior ainda, morrer e cair no esquecimento dos demais. Se a criatura tem todos esses traços, nâo seria ela, entâo, humanizada?

Se formos pensar o corpo da criatura Frankenstein e compararmos com o físico de um ser humano, podemos ver disparidades gritantes: é um ser extremamente alto, forte, rápido. Porém, sua criaçăo e estrutura é baseada na nossa: possui dois braços, duas pernas. Enfim, o que mais aproxima o monstro do ser humano é a sua capacidade de desenvolver a linguagem, essencial para a comunicaçâo. Nos estudos de Émile Benveniste, importante linguista estruturalista, entendemos que:

A linguagem humana caracteriza-se justamente aí. Cada enunciado se reduz a elementos que se deixam combinar livremente segundo regras definidas, de modo que um número bastante reduzido de morfemas permite um número considerável de combinaçôes - de onde nasce a variedade da linguagem humana, que é a capacidade de dizer tudo. Uma análise mais aprofundada da linguagem mostra que esses morfemas, elementos de significaçăo, ainda menos numerosos, cuja reuniăo seletiva e distintiva fornece as unidades significantes. Esses fonemas "vazios", organizados em sistemas, formam a base de todas as línguas. Está claro que a linguagem das abelhas năo permite isolar semelhantes constituintes; năo se reduz a elementos identificáveis e distintivos. $\mathrm{O}$ conjunto dessas observaçóes faz surgir a diferença essencial entre os processos de comunicaçăo descobertos entre as abelhas e a nossa linguagem. [...] a sociedade que é a condiçấo da linguagem. (BENVENISTE, 2005, p. 66)

Todo ser humano socializado possui uma linguagem, podendo dominar náo apensas sua língua, mas a de outras regiōes. A criatura de Victor, mesmo năo sendo considerada humana, conseguiu desenvolver a linguagem do meio em que vivia, nâo precisando se comunicar por meio de códigos - que é o meio de comunicaçăo dos animais (zoo). Essa capacidade nada mais é do que uma característica plenamente humana do monstro: no início de sua história, ele relata para Victor como ele aprendeu a se comunicar, desde quando se refugiou na casa de uma família pela qual ele secretamente se apegou, observando-os, dentro de um esconderijo, e deduzindo como funcionavam suas vidas:

Percebi que aquelas pessoas tinham um método para comunicar suas experiências e seus sentimentos umas às outras por sons articulados. Notei que as palavras que falavam algumas vezes produziam prazer, noutras sofrimento, oras sorrisos, ora tristeza, na mente e no rosto de quem as ouvia. Era, de fato, uma ciência dos deuses aquela, e ardentemente desejei me familiarizar com ela. Mas ficava confuso a cada tentativa que fazia nesse sentido. A pronúncia deles era rápida e as palavras que diziam, náo tendo aparentemente nenhuma ligaçăo com objetos visíveis, deixavamme sem pistas de como decifrar o mistério de sua referência. No entanto, com grande dedicaçấo, [...] descobri os nomes dados a alguns objetos que mais apareciam 
no discurso; aprendi e passei a usar as palavras 'fogo', 'păo' e 'madeira'. (SHELLEY, 2015, p. 200)

No trecho acima, podemos comparar o monstro como uma criança humana que ainda náo consegue falar, mas que, ao associar os sons das palavras com os objetos do seu dia a dia, vai desenvolvendo seu léxico. As observaçóes realizadas pela criatura demandaram tempo e dedicaçấo e, além delas, a criatura pode contar com o auxílio da leitura de alguns livros que encontrava pela casa: "O chalé de meus protetores fora minha única escola no estudo da natureza humana" (p. 220). Enfim, o monstro se torna uma criatura que, por meio da observaçâo e estudo, consegue desenvolver a linguagem, mesmo que năo tenha tido a oportunidade de praticá-la seguidamente nas interaçôes sociais.

O ser humano se desenvolve dentro de um processo histórico cultural, o que ocorre apenas com seres naturalmente racionais. Muito mais do que a realizaçăo de atividades apenas com o objetivo de sobrevivência, o ser humano consegue refletir sobre elas, observando e realizando experimentos. Na obra, o monstro de Frankenstein era dotado de uma inteligência fora do comum, conseguindo desenvolver linguagem e técnicas de sobrevivência apenas por meio da observaçăo e deduçấo:

Certo dia, atormentado pelo frio encontrei uma fogueira deixada por vagabundos errantes e me vi tomado de prazer com a sensaçáo de calor que experimentei. Em meu contentamento, enfiei a măo na brasa viva, mas depressa a recolhi com um grito de dor. Como era estranho, pensei, que efeitos opostos tivessem a mesma causa! Examinei o material da fogueira e, para minha alegria, descobri que era madeira. Náo demorei a juntar alguns galhos; mas estavam úmidos e náo queimaram. Fiquei triste com isso e ali e sentei, ainda a observar como funcionava o fogo. A madeira molhada que eu havia colocado perto do calor secou, ela própria acabando por se incendiar. Refleti a respeito e, tocando os vários galhos, descobri qual era a causa daquilo, e me pus a coletar grande quantidade de madeira que pudesse secar para obter um estoque abundante de fogo. (p. 191, grifos nossos)

Até entăo, listamos alguns fatores que podem classificar a criatura como um ser de traços humanos, sendo eles a carência afetiva devido à ausência paterna, sua falta de interaçăo social por năo ser reconhecido por nenhum indivíduo, sua capacidade de desenvolver linguagem e sua inteligência e poder de reflexăo. Além disso, podemos destacar como importante, também, sua agressividade - a qual se desenvolve pela rejeiçăo e falta de reconhecimento.

Quando a criatura recebe vida, ela năo é agressiva: sua rebeldia nada mais é do que uma resposta à sociedade que năo a aceita. Além do mais, durante suas inúmeras tentativas de socializaçâo, ela é tratada com violência extrema por ter uma aparência horripilante. O que ocorre é que, durante sua vida, o monstro năo teve a oportunidade de educaçấo, ao contrário do que todo o indivíduo humano possui, desde seu nascimento e inserçăo na sociedade. Tal processo de educaçăo, no sentido comportamental, é realizado utilizando o corpo, pois ele é o meio de readequaçăo da mente. Há penalidades físicas e morais, como beliscóes ou isolamento (castigo). Sobre essa temática, o filósofo e teórico social Michel Foucault disserta, em sua famosa obra Vigiar e Punir, a qual trata das entidades estatais (hospitais, escolas e prisóes) e seus métodos de disciplina. 
Na oficina, naescola, noexército funciona comorepressoratoda umamicropenalidade do tempo (atrasos, ausências, interrupçôes das tarefas), da atividade (desatençăo, negligência, falta de zelo), da maneira de ser (grosseria, desobediência), dos discursos (tagarelice, insolência), do corpo (atitudes "incorretas", gestos nâo conformes, sujeira), da sexualidade (imodéstia, indecência). Ao mesmo tempo é utilizada, a título de puniçăo, toda uma série de processos sutis, que vâo do castigo físico leve a privaçóes ligeiras e a pequenas humilhaçóes. Trata-se ao mesmo tempo de tornar penalizáveis as fraçóes mais tênues da conduta, e de dar uma funçáo punitiva aos elementos aparentemente indiferentes do aparelho disciplinar: levando ao extremo, que tudo possa servir para punir a mínima coisa; que cada indivíduo se encontre preso numa universalidade punível-punidora. (FOUCAULT, 1999, p. 203)

O monstro da história năo foi introduzido em nenhuma instituiçăo educacional e, além disso, por ter uma aparência bestializada, ele era diariamente punido por existir. Tendo em vista que o corpo está em constante atuaçăo, o monstro năo sabia como agir civilizadamente, sabendo o que era correto ou incorreto no momento de lidar com pessoas, principalmente pelo fato de náo terem lhe dado oportunidade para tal. Portanto, ao ser tomado por seus instintos naturais e primitivos, o mostro năo consegue controlá-los, pois náo foi criado com um acompanhamento institucional, tanto da escola quanto da família.

Retomando o que foi colocado anteriormente, o monstro se comporta violentamente como uma resposta ao que sofria da sociedade: exclusăo, hostilidade, violência física e moral:

Mal havia me escondido e uma menina passou correndo pelo local de meu esconderijo, rindo, como se fugisse de alguém por brincadeira. Continuou pela margem íngreme do rio, quando, de repente, seu pé escorregou e ela caiu na correnteza veloz. Precipitei-me de meu esconderijo e, com muito esforço por conta da força da correnteza, salvei a menina, puxando-a para a margem. Ela estava inconsciente e empenhei-me, por todos os meios a meu alcance, em reanimá-la, no que súbito fui interrompido pela aproximaçấo de um camponês, o qual era provavelmente a pessoa de quem a menina, brincando, fugia. Ao me ver, ele voou na minha direçăo e arrancou a menina dos meus braços, escapando às pressas para os recessos mais profundos da mata. Apressei-me a segui-los, năo sei bem por quê, mas, quando viu que eu me acercava deles, o homem apontou uma arma e atirou contra meu corpo. Desabei no chăo e meu agressor, com agilidade ainda maior, desapareceu na floresta. Foi essa a recompensa por minha benevolência! Tinha salvado um ser humano da destruiçáo e, como prêmio, vi-me contorcendo miseravelmente de dor em razáo de um ferimento que estilhaçara carne e osso. Aqueles sentimentos de bondade e gentileza que eu acalentava náo mis que poucos momentos antes deram lugar a uma fúria diabólica e ao ranger de dentes. Inflamado pela dor, jurei ódio e vingança eternos à espécie humana. (SHELLEY, 2015, p. 234)

Este episódio foi crucial e decisivo na vida do monstro, e é a prova de que ele tinha sentimento de humanidade com os indivíduos de uma espécie que năo o aceita. Ele se identifica com os seres humanos, a ponto de tentar interagir com eles, mas isso náo é recíproco.

Assim como todo ser humano, o monstro de Frankenstein tem o medo de năo ser reconhecido e cair no esquecimento. Seu maior desejo é ser reconhecido por seu criador, que é sua referência paterna - tendo em vista que năo o é, desenvolve um paradoxo sentimental, ferindo aqueles que Victor ama, para atingi-lo negativamente e, ao mesmo tempo, chamar a atençâo do médico para suprir a carência afetiva: "Maldito, 
maldito criador! Por que vingou em mim a vida? Por que năo extinguiu, naquele instante, a centelha da existência com que tăo levianamente me presenteaste?" (p. 228). Sem nem ter recebido um nome, o monstro jamais perpetuaria o legado cultural do nome de Frankenstein, o que poderia lhe ser concedido. A existência de seu criador é a única coisa que lhe mantém vivo e na constante busca por reconhecimento; por isso que, quando está em seu leito de morte, Victor recebe a última visita do monstro, que vai embora para sempre.

Por fim, finalizando este estudo, podemos concluir que o corpo é um vetor atuante, sendo uma fronteira que nos permite a experiência com o mundo exterior. Também, por ser o que nos permite a interaçáo com os demais indivíduos da sociedade, podemos nele fazer nossas manifestaçōes de identidade, ou utilizá-lo para pertencer a certos grupos identitários. No entanto, o corpo acaba sendo padronizado em certas instâncias, e aqueles que estăo fora de tal padrăo podem sofrer com a exclusăo, principalmente na questăo da aparência estética. Para isso, muitas pessoas acabam recorrendo a métodos alternativos para se adaptarem ao que lhes é cobrado - isso pode englobar a vestimenta, as cirurgias de estética, os cosméticos, e tudo mais que envolve o fator estético.

Dentre esses padrôes estabelecidos de ser humano ideal, temos o monstro criado por Victor Frankenstein. Assim como o Deus cristăo fez o homem a partir do barro, o médico também dá vida à matéria morta, mas se arrepende de sua criaçâo e a abandona, tomado pelo pavor de sua aparência horrenda e disforme - uma estética totalmente fora dos padrôes que a sociedade da época estabelece. A partir do abandono, surge, entăo, o monstro.

Conforme conhecemos a história do monstro de Frankenstein, dificilmente năo o humanizamos. Mas por que isso ocorre? Porque apesar de ser tratado como uma aberraçâo, sua capacidade de inteligência, discurso e afeto sâo idênticas as de qualquer ser de nossa espécie. Assim que apareceu para Victor, náo recebendo nem nome, foi largado à própria sorte, tendo que aprender sozinho a conseguir alimento e abrigo. Quando vai para o chalé e aprender a linguagem humana local por meio de observaçôes e leituras, acaba por desenvolver o afeto - outra característica humana. A partir de entăo, começam as decepçōes.

Quando se revela para a família a qual ele passa tempos observando, o monstro tem sua primeira tentativa de socializaçáo como uma experiência totalmente frustrante: é respondido com gritos, violência, ofensas e histeria. Como qualquer ser humanizado, isso lhe decepciona e o amargura, mas náo permite que ele perca esperanças em demais humanos. Nas demais tentativas que realiza, todos lhe tratam do mesmo modo - até mesmo as crianças, como William, irmâo mais novo de Victor (que acaba sendo assassinado).

Durante sua vida, o monstro é algo grotesco - é visto como uma figura horrenda, assustadora, năo civilizada, fora dos padróes estéticos, nâo humana. Porém, mesmo seu corpo sendo um amontoado de pedaços humanos, o monstro tem traços humanizados, como a benevolência, a linguagem, a inteligência, a carência e, principalmente, a necessidade de reconhecimento (especialmente paterno). Por nunca ter seus anseios correspondidos, ele vira um assassino, se vingando do mal que a sociedade lhe oferece. Mesmo sendo uma figura enorme, resistente e ameaçadora, a criatura é extremamente frágil, pois năo consegue constituir sua identidade no ambiente que vive - isso nos mostra que a interaçăo e o acolhimento săo essenciais para a nossa questăo identitária, permitindo que possamos nos desenvolver e constituir como sujeitos, sempre reconhecidos como tais. 


\section{REFERÊNCIAS}

BENVENISTE, Émille. Problemas de linguística geral. 5 ed. Săo Paulo: Pontes, 2005.

BÍBLIA. Português. Bíblia Sagrada. Săo Paulo: Editora EP Ltda, 1961.

CAMPELLO, Eliane; SCHMIDT, Rita. Apresentaçâo: corpo e literatura. In: Ilha do Desterro. v. 68, n² 2, p. 009-014, Florianópolis, mai/ago 2015.

FIORIN, J. L. A linguagem humana: do mito à ciência. Linguística? Que é isso? Săo Paulo: Contexto, 2013.

FOUCAULT, Michel. Vigiar e punir. Traduçăo: Raquel Ramalhete. 20 ed. Petrópolis: Vozes, 1999.

FREUD, Sigmund. O Estranho. In: Além do limite de prazer. Traduçăo de e Alix Strachey. Ediçâo Standard Brasileira, Vol. XVIII. Rio de Janeiro: IMAGO Editora, 1976.

HOGEMANN, Edna; MOURA, Solange. O direito fundamental à identidade pessoal e o estigma do abandono. 1 ed. Săo Paulo: Revista dos Tribunais, 2013. V. 01/02. p. 58.

LIMA, Marisa. Do corpo sob o olhar de Bordieu ao corpo contemporâneo. In: Seminário Nacional Corpo e Cultura, 4., 2013, Goiânia. Anais (online). Goiânia: FE-UFG, 2013. Artigos. Disponível em: 〈http://congressos.cbce.org.br/index.php/4sncc/2013/paper/ viewFile/5746/2971>. Acesso em 25 Jun 2017.

PAIVA, Raquel; SODRÉ, Muniz. O império do grotesco. Rio de Janeiro, Mauad, 2002.

SHELLEY, Mary. Frankenstein ou o Prometeu moderno. São Paulo: Penguin Classics Companhia das Letras, 2015.

SILVA, Tomaz Tadeu. A produçăo social da identidade e da diferença. In: (org). Identidade e diferença - a perspectiva dos estudos culturais. Petrópolis: Vozes, 2000, 133p.

WOODWARD, Kathryin. Identidade e Diferença: uma introduçâo teórica e conceitual. Identidade e diferença - a perspectiva dos estudos culturais. Tomaz Tadeu SILVA (organizador). Petrópolis: Vozes, 2000, 133p. 